\title{
IMPACTUL MIGRAṬIEI ASUPRA DINAMICII POPULAȚIEI MUN. CHIȘINĂU
}

\author{
Tatiana TABAC ${ }^{\odot}$, drd., cercetător științific, \\ Centrul de Cercetări Demografice al INCE, Republica Moldova \\ DOI: https://doi.org/10.36004/nier.cdr.2019.14-20 \\ JEL Classification: J11, F22, R23, C53.
}

Municipiul Chișinău este cea mai dezvoltată regiune a țării, aici fiind concentrat cel mai semnificativ potențial uman și financiar. Dezvoltarea socioeconomică avansată comparativ cu alte localități menține sporul natural și migrațional pozitiv. Scopul cercetării a constat în determinarea impactului migrației asupra dinamicii populației în mun. Chișinău în perioada dintre Recensământul Populației 2004 și a Recensământului populației și al locuințelor desfășurat în 2014. Metoda principală aplicată în cercetare a fost the cohort component method, sau metoda componentei. Calculele realizate au permis identificarea profilurilor pe vârste și sexe ale populației închise și profilul populației migrante. Rezultatele obținute demonstrează contribuția negativă a migrației externe în dinamica populației municipiului, factorul principal de stabilizare a situației fiind sporul migrațional intern pozitiv. Cea mai importantă reducere a fost din contul populației tinere în vârstele de 28-31 de ani, precum și a populației în vârstele apte de muncă. Migrația netă în mun. Chișinău în perioada de referință este negativă și reprezintă minus 40 mii persoane, populația fiind în scădere cu 7,3\%. Cercetarea a demonstrat că populația în municipiu crește grație populației de vârstă tânără încadrate în procesul de studiu. Cu toate acestea, menționăm că localitatea devine tot mai puțin atractivă pentru tinerii din Republica Moldova.

Cuvinte-cheie: impactul migrației, perioada intercensitară, depopulare, metoda componentei, mun. Chișinău.

Chisinau municipality is the most developed region of the country, concentrating the most significant human and financial potential. Due to the higher socio-economic development compared to other localities, in Chisinau is maintained natural and migratory growth. The purpose of the research was to determine the impact of migration on the population dynamics in Chisinau municipality during the period between the 2004 Population Census and the 2014 Population and Housing Census. The main method applied in the research was the cohort component method, or the component method. The estimations made it possible to identify the age and gender profiles of the closed population and the profile of the migrant population. The results show the negative contribution of the external migration in the dynamics of the population of the municipality, the main stabilizing factor of the situation being the positive internal migration. The most significant decrease was of the young population aged 28-31, as well as of the working-age population. The net migration to Chisinau municipality in the reference period is negative and represents minus 40 thousand people, the population decreasing by 7.3\%. Research has shown that the population in the municipality grows thanks to the young students. However, the locality is becoming less attractive for young people from the Republic of Moldova.

Key words: impact of migration, intercensitar period, depopulation, cohort component method, Chisinau municipality.

\section{Introducere}

Municipiul Chișinău este cea mai dezvoltată regiune a țării din punct de vedere economic, social și cultural. Aici este concentrat cel mai semnificativ potențial uman și financiar de care

\footnotetext{
${ }^{\circledR}$ Tatiana Tabac, tania.tabac@gmail.com
} 
dispune țara, universitățile, corporațiile mari, toate instituțiile de conducere. Potrivit datelor Recensămintelor populației din anii 1989 și 2004, în mun. Chișinău locuiau 21\% din toată populația țării, iar în anul 2014 - 17\% (22\% raportat la populația estimată). Datorită dezvoltării economice avansate comparativ cu alte regiuni, în fiecare an populația din alte localități se stabilește cu traiul în capitală. În acest sens, Recensământul din anul 2014 a arătat că din cele 469,4 mii persoane recenzate, 245 mii locuiesc în Chișinău de la naștere și 210 mii nu de la naștere, ceea ce semnifică $45 \%$.

Diferențieri semnificative există și în dezvoltarea demografică a mun. Chișinău comparativ cu alte localităţi. La momentul actual, municipiul ocupă cea mai bună poziție în ceea ce privește sporul natural și migraţional înregistrat conform statisticii curente a populației. Potrivit datelor BNS, în anul 2011 sporul natural a constituit 1,9\%o, iar în anul 2014 - 0,9\%o. Totodată, sporul migrațional intern estimat pentru anul 2014 a fost cel mai ridicat din republică - 6\%o, după care a urmat mun. Bălţi cu 3,7\% [2, p.59]. Echilibrul demografic împreună cu dezvoltarea socioeconomică plasează mun. Chișinău pe cea mai superioară poziție față de alte raioane în ceea ce privește Indicele Integral Teritorial de Securitate Demografică (IITSD) [3, p.7].

Deși la prima vedere statisticile demonstrează o poziţie demografică favorabilă pentru mun. Chișinău, acest studiu demonstrează existența unui risc efectiv de deteriorare a situației în ceea ce privește evoluția populației în viitor. $\mathrm{Cu}$ alte cuvinte, așa cum este demonstrat în continuare, localitatea se confruntă cu scăderea considerabilă a populației tinere, precum și a populației în vârstele apte de muncă.

\section{Date și metode}

Metoda principală utilizată în cercetare este cohort component method, numită și metoda componentei, (руc. метод передвижки возрастов или метод дожития), utilizată pe larg în modelarea matematică a numărului și compoziției populației. Metoda componentei a fost dezvoltată de cercetătorul american Pascal K. Whelpton [4, 5] în prima jumătate a sec. al XIX-lea și utilizată pe larg de către demografi în analiza prospectivă și retrospectivă a proceselor demografice $[1,6,7$, 8], precum și în realizarea prognozelor demografíce. În cercetarea de față, această metodă permite observarea numărului migranților neînregistrați de statistica curentă, comparând schimbările care au avut loc în cohortele de populație. Principiul analizei este că populația care s-a aflat pe teritoriul mun. Chișinău în anul 2004 fie a rămas să locuiască pe acest teritoriu până în anul 2014, fie că a plecat să locuiască pe un alt teritoriu (din țară sau peste hotare), fie a decedat. Tot aici se mai adaugă și populația care s-a născut în perioada de referință.

Pentru analiză au fost utilizate datele statisticii curente privind numărul și distribuția pe sexe a născuților-vii în fiecare an în perioada 2004-2014 și numărul decedaților pe sexe și vârste în fiecare an din 2004 până în 2014. Alte date importante incluse în analiză au fost numărul populației pe fiecare vârstă și sexe la Recensămintele din 2004 și 2014. Toate datele și calculele se referă la mun. Chișinău.

\section{Rezultate obținute}

Potrivit statisticii curente, numărul populației în mun. Chișinău a crescut de la 721 mii persoane la 780 mii persoane în perioada 1989-2018. Totodată, recensămintele desfășurate arată descreșterea populației de la 771 mii persoane în anul 1989 la 712 mii persoane în anul 2004 şi la 662 mii persoane în anul 2014 (Fig. 1. $)^{36}$. Diferențe majore dintre aceste două surse de date este explicată prin înregistrarea scăzută a fluxurilor de intrare și ieșire a populației pe acest teritoriu.

Problema majoră cu care se confruntă statistica curentă este neobligativitatea persoanei de a anunța oficial venirea și plecarea din localitate. Astfel, în statistică sunt incluse doar persoanele care dețin viza de reședință, indiferent de locul aflării persoanei la momentul observării.

\footnotetext{
${ }^{36}$ Datele prvind populaţia estimată prezentate de BNS.
} 
Întrebarea importantă în acest context este: "Care este numărul real al migranților în mun. Chișinău și cum acesta s-a modificat în perioada intercensitară?". Luând în considerație faptul că migrația spre mun. Chișinău este mai sporită decât spre alte localități, putem presupune că populația este sau cel puțin trebuie să fie în creștere datorită sporului migrațional intern pozitiv înregistrat [2, p. 59]. Cu toate acestea, creșterea continuă a fluxurilor migraționale internaționale are loc în toată țara, astfel efectivul populației e posibil să scadă și în mun.Chișinău. Această analiză a fost realizată cu scopul de a oferi răspuns la întrebarea privind contribuția migrației în dinamica populației mun.

Chișinău.

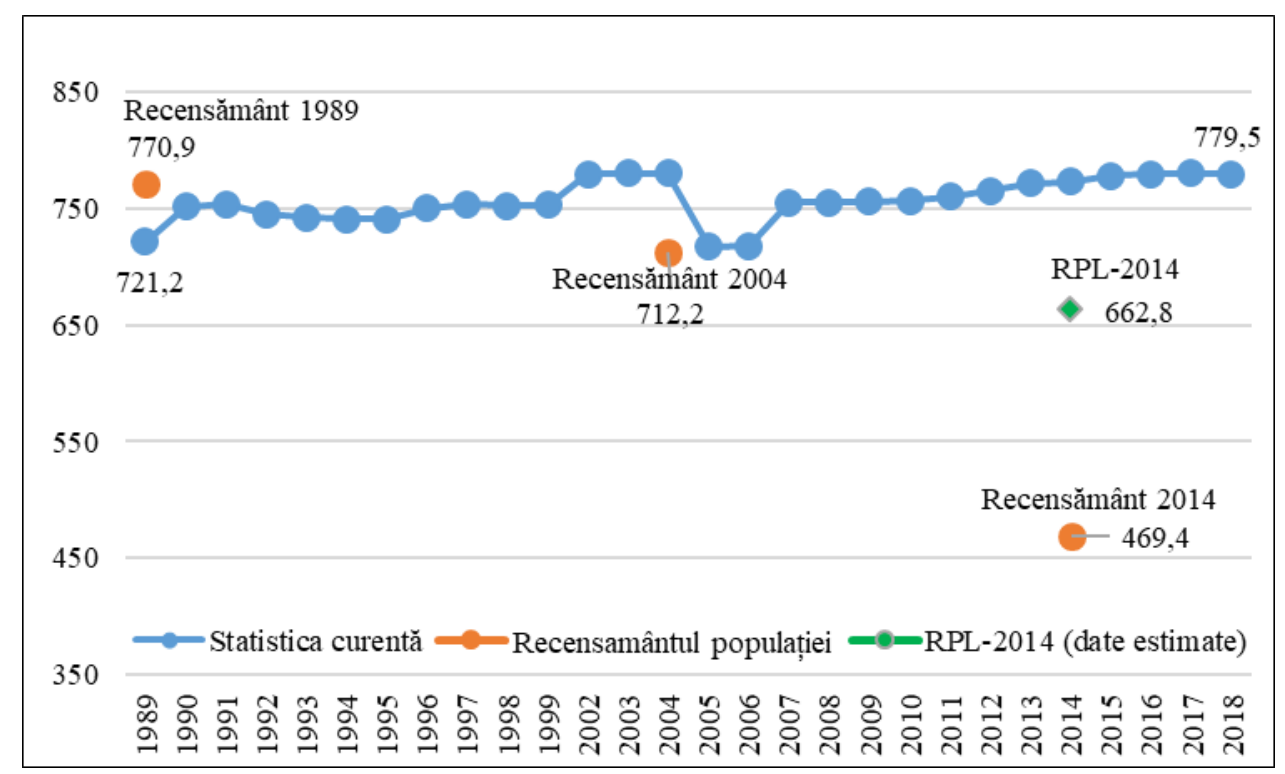

Figura 1. Dinamica numărului populației în mun.Chișinău în anii 1989-2018,

Sursa: BNS mii persoane

Datele statistice disponibile ne-au oferit posibilitatea să pornim analiza de la Recensământul populației desfășurat în 2004.

Calculele realizate în baza celor două surse de date (statistica curentă și statistica recensămintelor) au ca finalitate identificarea profilurilor pe vârste și sexe ale populației mun. Chișinău cu diferențierea pe populația închisă și populația migrantă. Populația închisă se referă la populația care locuiește în mun. Chișinău în perioada celor două recensăminte, ținând cont de toți cei născuți și decedați. Populația migrantă sunt persoanele care au venit sau au plecat în această perioadă de timp.

În Fig. 2 este prezentată populația pe vârste și sexe la Recensământul din 2004 - populația iniţială care a stat la baza calculelor. În Fig. 3. este reprezentat profilul pe vârste și sexe al populației estimate în anul 2014 - ceea ce a fost numit populaţie închisă.

Rezultatele din Fig. 3. ne arată populația închisă estimată pentru anul 2014 în care observăm deplasarea în sus a populației tinere de vârstele 18-21 de ani la vârstele de 28-31 de ani. Tot aici constatăm populația numeroasă în vârsta aptă de muncă, dar și majorarea populației în vârsta de 60 ani și peste. 


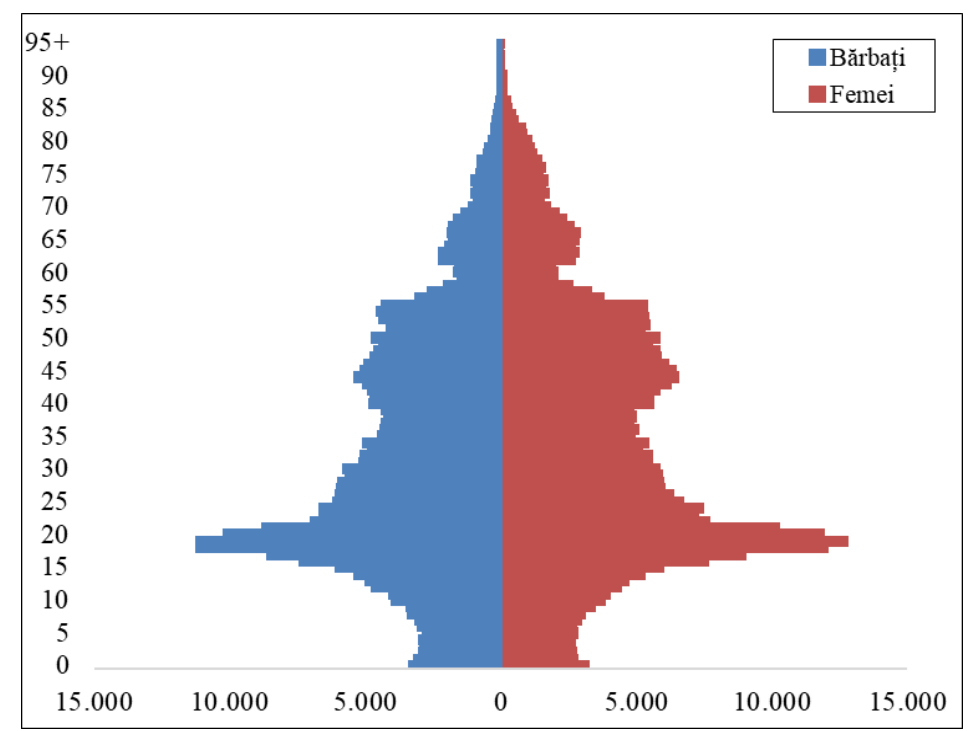

Figura 2. Piramida pe vârste și sexe a populației mun. Chișinău la RP-2004, Sursa: BNS mii persoane

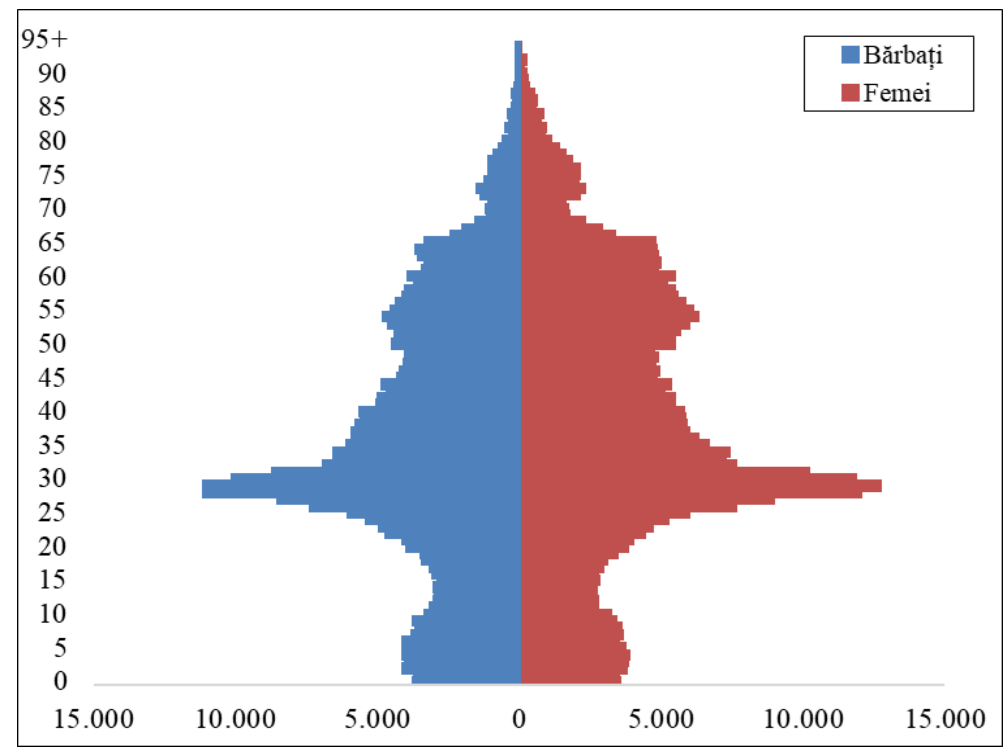

Figura 3. Piramida pe vârste și sexe a populației închise a mun. Chișinău în 2014, mii persoane

Sursa: estimările autorului în baza datelor BNS

Contribuția migrației la dinamica populației este redată în Fig. 5. Rezultatele obținute demonstrează descreșterea populației datorită migrației. Potrivit datelor RPL-2014, în perioada analizată a avut loc o scădere enormă a populației în vârstele tinere de 20-40 de ani și o descreștere uşoară a populației în vârstele apte de muncă.

Figura 5. prezintă concomitent două tipuri de populație: populaţia închisă pentru anul 2014 estimată conform metodei componentei și datele RPL-2014, fiecare în funcție de sexe și vârste. Soldul migrației reprezintă diferența dintre aceste două tipuri de date. Rezultatele cercetării au scos în evidență în primul rând reducerea din contul migrației a populației tinere în vârstele de 28-31 de ani, precum și a populației în vârstele apte de muncă. Totodată, a fost constatată creșterea populației în vârstele de 18-24 de ani datorită soldului migrațional pozitiv.

Potrivit estimărilor efectuate, migrația netă în mun. Chișinău în perioada de referință este negativă şi reprezintă minus 40 mii persoane, populația fiind în scădere cu -7,3\%. 


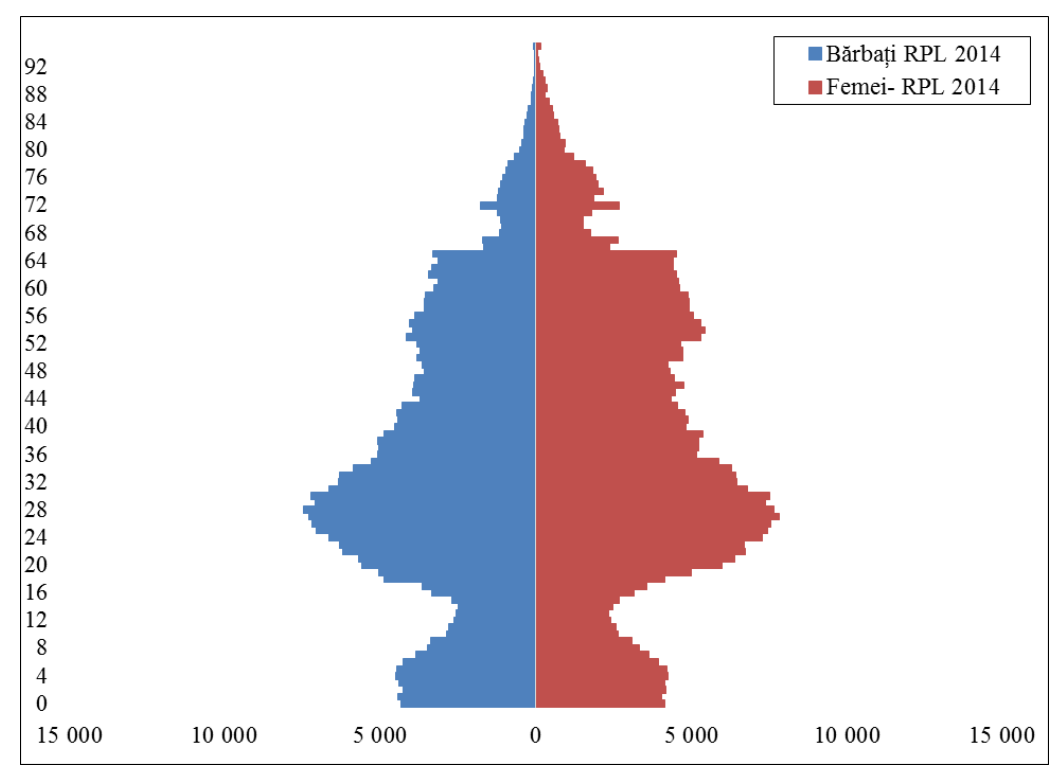

Figura 4. Piramida pe vârste și sexe a populației mun. Chișinău la RPL-2014, mii persoane

Sursa: BNS

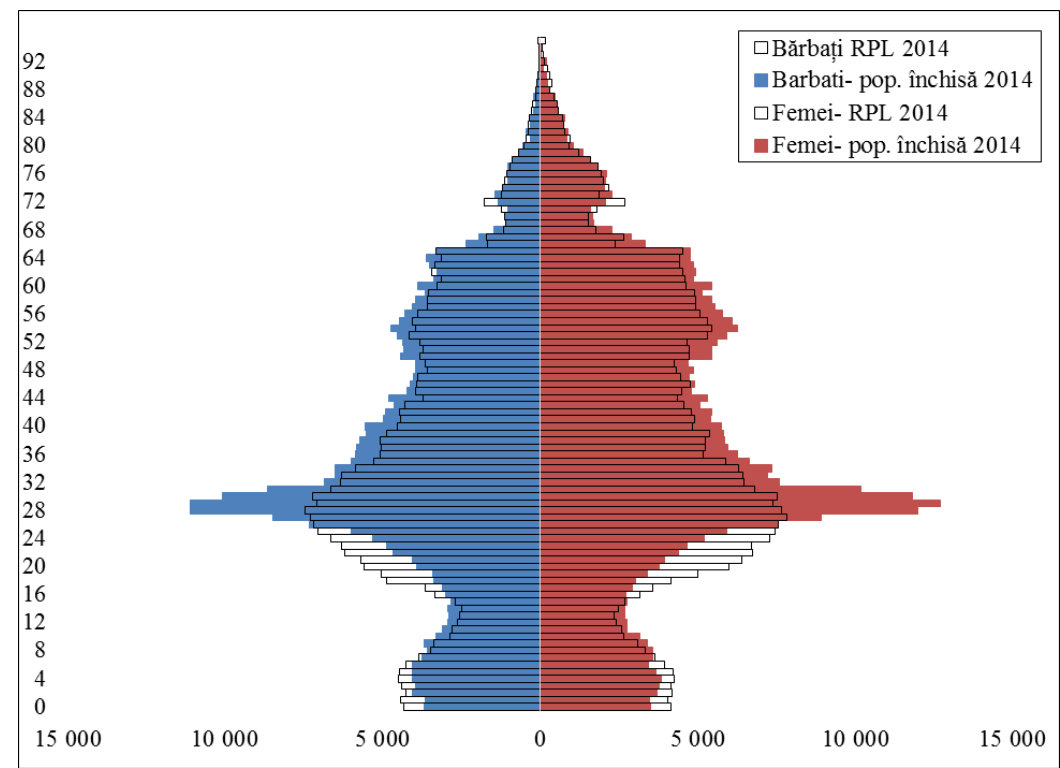

Figura 5. Piramida pe vârste și sexe a populației închise cu estimarea migrației, mun. Chișinău, 2014, mii persoane

Sursa: estimările autorului în baza datelor BNS

Figurile 6. şi 7. demonstrează soldul migrației estimat în anul 2014 în funcție de fiecare vârstă și sexe. Rezultatele obținute arată soldul migrației pozitiv în vârstele copilăriei de 0-7 ani și la vârstele de 16-25 de ani - vârstele specifice perioadei în care persoanele tinere sunt încadrate în procesul de studiu (Fig. 6.). O situație asemănătoare este observată atât la femei, cât și la bărbaţi (Fig. 7.). În celelalte grupe de vârstă soldul migrației este negativ. Cea mai mare pierdere a fost în vârstele de 28-31 de ani, populația a scăzut cu 30 mii persoane. Cea mai accentuată descreștere a fost înregistrată în rândul femeilor de această vârstă (Fig. 7.).

Rezultatele cercetării mai arată că populația în vârstele reproductive de $25-49$ de ani s-a redus cu 51 mii persoane, dintre care 56\% sunt femei. În același timp, populația în vârstele apte de muncă de 22-59 de ani s-a micşorat cu 52 mii persoane, însă datorită sporului migrațional pozitiv înalt la vârstele de 22-25 de ani scăderea a fost mai lentă. 
Trebuie să menționăm, că migrația negativă înregistrată în mun. Chișinău în perioada de analiză în cea mai mare măsură se datorează migrației populației peste hotare țării, și mai puțin migrației interne, or puține regiuni din republică înregistrează un spor migrațional intern pozitiv.

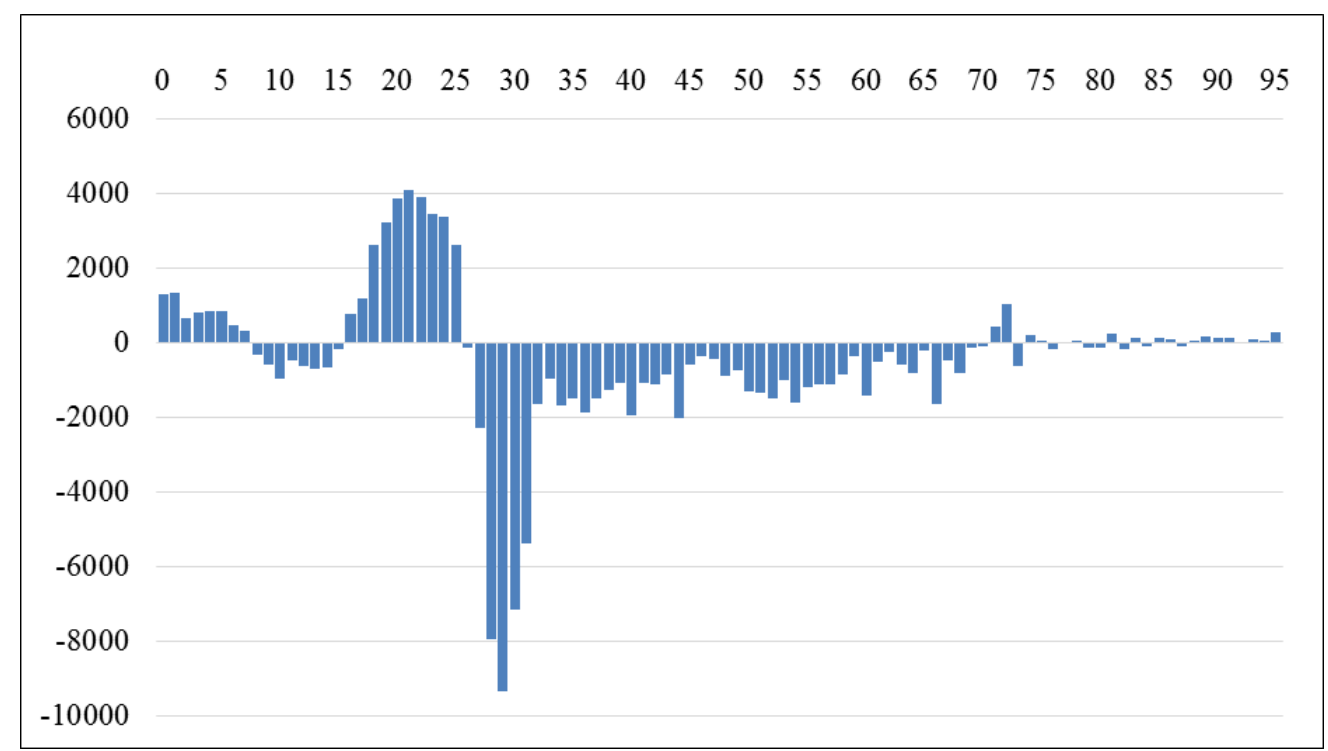

Figura 6. Soldul migrației în mun. Chișinău în perioada intercensitară, mii persoane

Sursa: estimările autorului în baza datelor BNS

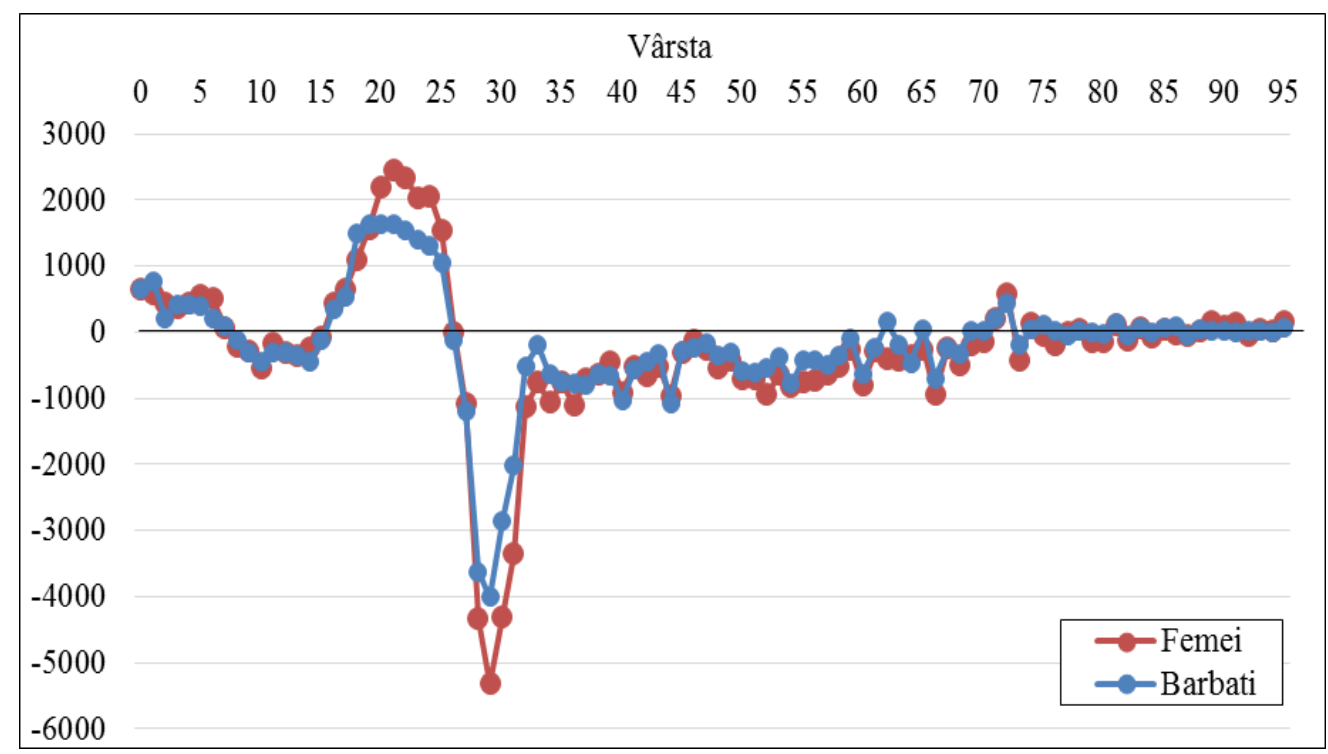

Figura 7. Soldul migrației pe sexe în mun. Chișinău în perioada intercensitară, mii persoane

Sursa: estimările autorului în baza datelor BNS

\section{Concluzii}

Până nu demult, populația mun. Chișinău a fost în creștere permanentă datorită sporului natural și migrațional intern pozitiv. Începând cu mileniul al doilea, populația municipiului a început să scadă, Recensământul anului 2004 pentru prima dată a înregistrat tendința de descreștere a populației în capitală. Ținând cont de fluxurile masive de emigranți din toată țară, factorul principal al acestei scăderi este considerat migrația externă a populației.

În acest context, observăm că mun.Chișinău se află între două fluxuri importante de migranți: fluxurile de migranți interni și migranți externi. Spre deosebire de multe alte regiuni din 
republică, în mun. Chișinău există sporul migrațional intern pozitiv, ce stabilizează evoluţia și dinamica populației. Dacă n-ar exista fluxuri sporite spre Chișinău, atunci, din cauza migrației externe, localitatea s-ar fi confruntat cu binecunoscutele probleme de depopulare, scădere semnificativă a populației apte de muncă, îmbătrânire demografică etc.

Rezultatele cercetării au demonstrat că populația crește în special grație populației de vârstele tinere, a persoanelor încadrate activ în procesul de studiu. Cu toate că RP în anul 2004 a înregistrat o proporție imensă a populației de vârstă universitară, totuși pe piramida RPL din 2014 este observată absența acestor persoane, ceea ce semnifică că deja și capitala este puțin atractiv pentru tinerii din Republica Moldova.

Este greu de afirmat care va fi evoluția populației în mun. Chișinău în următorii ani. Pornind de la tendințele recente, precum și de la prognoza privind situația demografică viitoare în țară, considerăm că reducerea populației va fi un proces continuu în localitate. Degradarea stucturii pe vârste și sexe determinată de scăderea populației tinere și apte de muncă din țară pe fundalul reducerii fertilității și creșterii intensității migrației, precum și aprofundarea procesului de îmbătrânire demografică vor avea un impact nefavorabil asupra dezvoltării socioeconomice și demografice a mun. Chișinău.

\section{Bibliografie}

1. Bogue D. Tehniques of Estimating Net Migration. Community and Family Study Center: 1982.

2. Gagauz O. (coord.) et al. Population Situation Analysis in Republic of Moldova. UNFPA, CCD/INCE: 2016, 174 p.

3. Gagauz O., Pahomii I. Securitatea Demografică din perspectiva situației în unităţile administrativ-teritoriale. Creșterea Economică în Condiţiile Globalizării, Sesiunea știinţifică: Dinamica populației și calitatea potențialului uman: conferința internațională științifico-practică, 12 13 octombrie 2017. Ediția a 12-a. Chișinău: INCE, 2017, p. 6-16.

4. Whelpton P.K. Population of the United States, 1925 to 1975. The American Journal of Sociology, 1928, 34(2), p. 253-270.

5. Whelpton P.K. An empirical method of calculating future population. In: Journal of the American Statistical Assosiation, 31, 1936, p. 457-473.

6. Wunsch G.J., Termote M. Introduction to demographic analysis: principles and methods. Plemun Press: 1978.

7. Китова К. Роль миграции в изменение населения Москвы и Московской области: опыт оценки на основе материалов переписи 1989, 2002 и 2010 года. ДемоскопWeekly, 2012, № 519-520.

8. Назаров А.А., Носова М.Г. Метод передвижки возрастных групп в демографии и его приложения. Вестник Томского государственного университета, 2009, 3(8), p. 67-74. 